\title{
Science Academies' Refresher Course on Bioresources: Prospecting, Utilization, and Conservation 1-14 November 2017
}

\author{
at \\ Department of Zoology, Saiva Bhanu Kshatriya College \\ Aruppukottai-626 101, Virudhunagar Dt, Tamil Nadu \\ Sponsored by \\ Indian Academy of Sciences, Bengaluru \\ Indian National Science Academy, New Delhi \\ The National Academy of Sciences, India, Allahabad
}

The bioresources constitute the elements of biodiversity that are directly or indirectly useful to humans. Therefore bioresources can be considered as the biological treasure of any country. This course is intended to create awareness among the participants on diverse tools and techniques available to digitize, prospect, utilize and conserve the biological resources.

A brief outline of the course is as follows: Documenting and digitizing bioresources and traditional knowledge; mapping and quantifying bioresources; using traditional and other knowledge sources for prospecting bioresources; bioresources as raw material for biotechnology and bio-prospecting; biotechnological tools for conservation, genetic resource and bio-diversity, DNA finger printing technology and applications, functional genomics and targeted genome editing, genetic engineering. The course will comprise of lectures, tutorials and experiments.

Applications are invited from teachers with experience in teaching undergraduate and postgraduate courses in Life Sciences. Maximum 35 applications will be considered and teachers who wish to participate in the Refresher Course may apply through proper channel with the following details: name, date of birth, gender, Email, official and residential addresses, telephone numbers, academic qualifications, courses taught, affiliation, positions held and tenure. It is also essential to submit a brief statement (between 250 and 500 words) as to why they think the Course will help to improve their classroom teaching of Life Sciences. There will be no application fee/registration fee.

Applications should be submitted ONLINE by clicking the following link:

http://web-japps.ias.ac.in: 8080/Refreshcourse/RCBPZ.jsp

A printed copy of the application approved by the Head of the institution should be sent by speed post to: Dr A Baskar, Course Coordinator (Refresher Course), Department of Zoology, Saiva Bhanu Kshatriya College, Aruppukottai-626 101, Virudhunagar Dt, Tamil Nadu, Mobile: 09442531854; Email: drarulbaskar@gmail.com. Outstation candidates will be provided local hospitality and round trip bus/train (three-tier AC) fare by the shortest route. Please note that participants have to attend the full duration of the Course. Arrival-October 31 and Departure-November 14, 2017.

Course Director: Prof. K N Ganeshaiah, Department of Forest and Environmental Sciences and School of Ecology and Conservation, University of Agricultural Sciences, GKVK, Bengaluru-560 065. (Mobile: 09342160639; Email: knganeshaiah@gmail.com)

Last date for receipt of applications: 26 September 2017

Selected participants will be informed by: 30 September 2017 